\title{
Penerapan "Sleep Education After Midnigth" Terhadap Peningkatan Kualitas Tidur Pasien DM Type 2 di RSUD Tarakan Jakarta
}

\author{
Ali Fendi, Asih Dwi Suryanti, Rika Mustika Abriyanti, Yani Sofiani, Abdu Rahim Kamil \\ Program Studi Spesialis Keperawatan Medikal Bedah Fakultas IImu Keperawatan \\ Universitas Muhammadiyah Jakarta
}

\begin{abstract}
Abstrak
Diabetes adalah suatu kondisi yang lama dan serius dengan dampak besar pada kehidupan individu dan keluarga. Diabetes mellitus adalah salah satu penyebab utama kematian pada orang dewasa dan diperkirakan menyebabkan empat juta kematian di seluruh dunia pada tahun 2019. Kegiatan ini adalah untuk mengetahui pengaruh Penerapan Sleep Education After Midnight terhadap peningkatan kualitas tidur pada penderita diabetes mellitus. Evidence Base Nursing Practice (EBNP) yaitu penggunaan teori dan informasi yang diperoleh berdasarkan pencarian melalui 3 sumber jurnal yaitu pubmed, cochrane dan proquest dari hasil informasi in akan diaplikasikan pada kegiatan praktik keperawatan untuk mendapatkan bukti kebenaran dari teori. 1). Dilihat dari usia bahwa diabetes mellitus banyak dialami oleh penderita dengan usia $>60$ tahun dan laki-laki lebih banyak menderita diabetes mellitus daripada perempuan. 2). Ada peningkatan kualitas tidur pasien diabetes mellitus setelah dilakukan intervensi "Sleep Education After Night". Didapatkan nilai pittsburgh Sleep Quality Index (PSQI) sebesar 8,47 sebelum dilakukan intervensi pada kelompok intervensi, kemudian dilakukan pengukuran kembali setelah dilakukan intervensi maka diperoleh nilai PSQI sebesar 2,47 dengan $P_{\text {value }} 0,00($ atau $<0,05)$ ini artinya Penerapan Sleep Education After Night memiliki hubungan yang signifikan terhadap peningkatan kualitas tidur pasien diabetes mellitus.
\end{abstract}

Kata Kunci : Sleep Education After Night, Kualitas Tidur, Diabetes mellitus Tipe 2.

\begin{abstract}
Background Diabetes is a long-standing and serious condition with a major impact on the lives of individuals and families. Diabetes mellitus is one of the leading causes of death in adults and is estimated to cause four million deaths worldwide in 2019. The purpose of this activity is to determine the effect of implementing Sleep Education After Midnight on improving sleep quality in people with diabetes mellitus. Method: Evidence Base Nursing Practice (EBNP), which is the use of theory and information obtained based on a search through 3 journal sources, namely pubmed, cochrane and proquest. The results of this information will be applied to nursing practice activities to obtain evidence of the truth of the theory. Results: 1). Judging from the age that diabetes mellitus is mostly experienced by patients with age $>60$ years and men suffer from diabetes mellitus more than women. 2). There is an increase in the quality of sleep of patients with diabetes mellitus after the "Sleep Education After Night" intervention. Conclusion: The Pittsburgh Sleep Quality Index (PSQI) value was 8.47 before the intervention was carried out in the intervention group, then measured again after the intervention, the PSQI value was 2.47 with a P-value of 0.00 (or <0.05). This means that the application of Sleep Education After Night has a significant relationship with improving the sleep quality of patients with diabetes mellitus.
\end{abstract}

Keyword : Sleep Education After Night, Sleep Quality, type 2 diabetes mellitus.

http://ejournal.urindo.ac.id/index.php/kesehatan

Article History :

Sumbitted 03 Desember 2021 Accepted 30 Desember 2021, Published 31 Desember 2021 


\section{PENDAHULUAN}

Diabetes adalah suatu kondisi yang lama dan serius dengan dampak besar pada kehidupan individu dan keluarga. Diabetes mellitus adalah salah satu penyebab utama kematian pada orang dewasa dan diperkirakan menyebabkan empat juta kematian di seluruh dunia pada tahun 2019. Prevalensi diabetes global pada tahun 2019 diperkirakan sebesar 9,3\% (463 juta orang), meningkat menjadi 10,2\% (578 juta) pada tahun 2030 dan 10,9\% (700 juta) pada tahun 2045 ( IDF, 2019). Pada tahun 2018 terdapat 34,2 juta orang atau $10,5 \%$ dari populasi penduduk Amerika Serikat mengidap diabetes (DHHS, 2020). Di Indonesia terdapat 1.017.290 orang yang mengidap diabetes mellitus. Jawa Timur merupakan provinsi dengan angka paling banyak penderita diabetes sedangkan Jakarta berada pada posisi ke enam dengan angka 40.210 orang (Riskesdas, 2018). Kelompok Umur yang paling banyak menderita adalah 55-64 tahun sedangkan perempuan lebih dominan daripada laki-laki.

Terdapat 3 jenis DM yang paling sering terjadi adalah kesatu, diabetes mellitus tipe I merupakan jenis diabetes mellitus yang terjadi karena tubuh kurang atau sama sekali tidak memproduksi insulin, sehingga penderitanya harus menerima insulin dari luar. Kedua, diabetes mellitus tipe II yaitu suatu keadaan dimana sel pankreas memproduksi insulin dalam jumlah yang terbatas sehingga kebutuhan tubuh akan insulin tidak terpenuhi. Biasanya diabetes mellitus tipe II terjadi pada orang dewasa dan lansia bahkan remaja yang obesitas. Ketiga, yaitu Diabetes mellitus gestasional merupakan diabetes yang muncul pada masa kehamilan dan hanya berlangsung hingga proses melahirkan. Hal ini terjadi karena tubuh memproduksi insulin yang tidak mencukupi untuk mengontrol kadar gula darah pada waktu hamil. Dari 3 jenis diabetes mellitus tersebut $85 \%$ adalah Diabetes meliitus tipe 2 .

Menumpuknya glukosa di dalam pembuluh darah melampaui kemampuan ginjal yaitu $180 \mathrm{mg} / \mathrm{dl}$, maka glukosa akan dikeluarkan bersama urine. Untuk mempertahankan agar urine yang dikeluarkan tidak terlalu pekat maka tubuh akan mengeluarkan urine sebanyak mungkin sehingga volume urine yang keluar akan banyak dan buang air kecil akan menjadi sering. Untuk mengatasi permasalahan tersebut maka muncullah rasa haus sehingga penderita DM selalu kehausan. Keinginan buang air kecil sering terjadi di malam hari (nokturia), hal ini akan menyebabkan terganggunya tidur penderita diabetes. Dalam keadaan normal, di saat tidur tubuh manusia mampu memproduksi lebih sedikit urin namun lebih kental, ini artinya pada orang yang sehat tidak perlu bangun pada malam hari untuk buang air 
kecil dan bisa tidur selama $6-8$ jam tanpa adanya keingingan untuk buang air kecil.

Tidur adalah kebutuhan dasar yang harus dipenuhi oleh setiap manusia. Tidur merupakan suatu keadaan tidak sadarkan diri dimana persepsi dan reaksi individu terhadap lingkungan terjadi penurunan atau menghilang dan dapat dibangunkan kembali dengan adanya rangsangan yang cukup (Kusnadi, 2013). Aktifitas tidur dikontrol oleh medulla spinalis (batang otak) tepatnya di Retikular acivating system (RAS) dan bulbar synchronizing region (BSR) yang berfungsi untuk mempertahankan keadaan bangun dan mempermudah untuk tidur. Terjadinya bangun dan tidur merupakan peran dari RAS dan BSR, dimana RAS akan melepaskan katekolamin untuk mempertahankan kewaspadaan dan agar tetap terjaga. Namun ketika RAS di otak mengalami kelelahan sehingga mengaktifkan BSR untuk merangsang pengeluaran serotonin yang menimbulkan rasa mengantuk dan tidur (Saputra, 2013).

Tidur terbagi menjadi dua tahap yaitu Rapid Eye Movement (REM) dan Non Rapid Eye Movement (NREM). Tidur NREM terjadi karena aktivitas gelombang otak bergerak sangat lambat yang ditandai dengan penurunan sejumlah fungsi fisiologis maupun metabolisme, kerja otot dan tandatanda vital seperti tekanan darah dan frekuensi nafas. Terjadi sekitar $75 \%$ sampai $80 \%$ dari waktu tidur. Tidur REM merupakan keadaan tidur yang tidak nyenyak, biasanya berlangsung rata-rata setiap 90 menit disertai dengan mimpi. Tidur malam dimulai dengan empat tahap yaitu tidur NREM, berlanjut dengan fase tidur REM, kemudian dilanjutkan dengan pergantian siklus antara NREM dan REM selama sisa tidur hingga pagi sekitar 4-6 siklus. Lamanya tidur pada fase REM dan NREM dapat menentukan kualitas istirahat dan kesegaran individu pada pagi hari. Pada tahap 1-4 kualitas tidur akan bertambah dalam sehingga pada tahap 3 - 4 seseorang akan sulit terbangun.

Pada penderita diabetes, gangguan tidur dapat disebabkan oleh sering terbangunnya pada malam hari atau karena sulit untuk tertidur (Insomnia). Prevalensi nokturia berat pada penyandang diabetes mellitus tipe 2 sekitar 25\% (Purnamasari, 2020). Wahyuningsih dalam penelitiannya menyatakan bahwa $82 \%$ penderita diabetes mellitus mengalami insomnia dan salah satu penyebabnya adalah nokturia. Beberapa terapi yang disarankan untuk mengatasi terjadinya insomnia adalah terapi farmakologi dan nonfarmakologi. Namun beberapa terapi farmakologi yang diberikan dapat memberikan efek samping. Untuk mengurangi efek samping yang ditimbulkan maka dapat diberikan terapi nonfarmakologi yaitu Sleep Education After Night. Sleep Education After Night merupakan suatu terapi untuk mengidentifikasikan dan memodifikasi perilaku dan lingkungan yang 
mempengaruhi tidur pasien diabetes. Beberapa kegiatan yang dilakukan berupa menekankan jadwal dan rutinitas tidur yang stabil, lingkungan yang ramah untuk tidur, menghindari zat-zat yang akan menggangu tidur, olahraga teratur, menghindari minuman berkafein, pil tidur, alkohol dan pengurangan stres.

\section{METODE}

Metode yang dilakukan dalam kegiatan ini adalah penerapan Evidence Base Nursing Practice (EBNP) yaitu penggunaan teori dan informasi yang diperoleh berdasarkan pencarian melalui 3 sumber jurnal elektronik yaitu pubmed, cochrane dan proquest dari hasil informasi ini akan diaplikasikan pada kegiatan praktik keperawatan untuk mendapatkan bukti kebenaran dari teori. Kegiatan ini dilaksanakan di Poli Rawat Jalan RSUD Tarakan Jakarta selama 3 Bulan yaitu dimulai pada Bulan Maret - Juni 2021. Kegiatan ini dilaksanakan melalui 3 tahap yaitu, Persiapan, pelaksanaan dan evaluasi.

\section{a. Persiapan}

1. Ners Spesialis Mengajukan surat permohonan ijin pelaksanaan Evidence Base Nursing Practice (EBNP) Sleep Education for Diabetes Mellitus Tipe 2 Who Sleep After Midnight dengan menyerahkan proposal yang di tujukan kepada bagian koordinator pendidikan dan pelatihan RSUD Tarakan dan Bidang Keperawatan.

2. Setelah disetujui kemudian Ners Spesialis melakukan sosialisasi kepada Kepala ruangan beserta perawat rawat jalan untuk sosialisasi metode penerapan Sleep Education for Diabetes Mellitus Tipe 2 Who Sleep After Midnight termasuk waktu, pelaksanaan dan evaluasi intervensi.

3. Kemudian Ners Spesialis berkoordinasi dengan perawat rawat jalan dalam penerapan Sleep Education for Diabetes Mellitus Tipe 2 Who Sleep After Midnight, yang dilakukan di poli rawat jalan.

b. Pelaksanaan

1. Tahap awal, Ners Spesialis mengidentifikasi pasien DM type2 (termasuk usia), melalui rekam medis (pasien rawat jalan).

2. Selanjutnya, Ners Spesialis mengidentifikasi pemeriksaan kadar glukosa darah, HBA1c (yang sudah ada dalam rekam medik), jika tidak ditemukan pemeriksaan HBA1C maka maka dikategorikan sebagai kriteria eksklusi.

3. Saat penerapan EBNP jumlah responden dibagi dua kelompok, yaitu kelompok 1 (A) sebagai 
kelompok kontrol dan kelompok 2

(B) sebagai kelompok intervensi.

4. Ners Spesialis melakukan perkenalan, menggali pengetahuan pasien terkait DM type 2 dan komplikasinya pada kelompok intervensi.

5. Ners Spesialis mengidentifikasi gangguan pola tidur melalui kuesioner PSQI.

6. Bila dari hasil identifikasi (poin 4) didapatkan adanya gangguan pola tidur pada pasien, maka tahap berikutnya adalah Ners Spesialis membuat kontrak waktu dalam pelaksananaan penerapan Sleep Education yaitu saat ditemukan pasien dengan kriteria poin 4 di hari yang sama dan dibagi menjadi 3 sesi dengan masing - masing 10 menit.

7. Ners spesialis memberikan intervensi terkait penerapan Sleep Education for Diabetes Mellitus Tipe 2 Who Sleep After Midnight berikut dengan modifikasi behaviour approach (FERRET) : (Food, Emotion, Routine, Restrict, Environment, Timing) melalui video (Materi Edukasi : (1) jangan minum apapun 30 menit sebelum tidur, (2) jauhi makanan dan kafein 3 jam sebelum tidur, (3) tanpa alkohol atau merokok 3 jam sebelum tidur, (4) tidak ada media elektronik (mis., $\mathrm{Hp}$, ipod, menonton TV) minimal 30 menit sebelum tidur, dan (5) Tidak berolahraga 3 jam sebelum tidur ). (Li et al., 2018)

8. Kegiatan dilanjutkan dengan melakukan diskusi tentang keuntungan dan kerugian dari penerapan Sleep Education After Midnight's ini sesuai dengan tingkat pengetahuan pasien.

9. Tahap selanjutnya Ners Spesialis melakukan evaluasi tahap pertama, pada kelompok intervensi pada pada minggu kedua, dengan menggunakan alat quesioner dan melampirkan lembar monitoring. Evaluasi tahap akhir akan dilakukan pada minggu keempat. (Li et al., 2018).

10.Kelompok kontrol tidak diberikan intervensi tetapi kelompok kontrol di evaluasi pada akhir penerapan EBNP melalui pengisian kuesioner secara langsung jika dalam pengisian kuesioner mengalami kendala maka evaluasi dilakukan melalui google form.

c. Setelah 2 minggu pelaksanaan penerapan Sleep Education After Midnight, dilakukan evaluasi kepada responden dengan melihat peningkatan kualitas tidur pasien. Pada tahap akhir, Ners Spesialis melakukan evaluasi akhir 
dan dianalisa dari penerapan EBNP. Selanjutnya Ners Spesialis melaporkan hasil analisa ini kepada RSUD Tarakan sebagai informasi untuk dapat dipertimbangkan dalam pengelolaan pembuatan SPO rencana tindak lanjut peningkatan kualitas tidur diabetisi dan kompetensi perawat terhadap penerapan Sleep Education After Night.

\section{HASIL DAN PEMBAHASAN}

hasil penerapan EBPN Sleep Education After Midnight' Terhadap Peningkatan Kualitas Tidur Diabetisi Type 2, yakni di mulai pada proses pengumpulan data dilakukan dari tanggal 29 Maret - 29 Juni 2021 di RSUD Tarakan Jakarta Pusat Tahun 2021. Adapun jumlah responden EBNP sebanyak 30 orang responden yang masing-masing dibagi menjadi 2 kelompok yaitu kelompok intervensi dan kelompok kontrol. Semua responden didapatkan dengan melakukan screening yang memenuhi kriteria inklusi dan eksklusi.

\section{A. Analisa Univariat}

Analisis univariat bertujuan untuk menjelaskan karakteristik variabel yaitu Usia, Jenis Kelamin, Lama Menderita Diabetes Melitus, Tinggi Badan dan Berat Badan.

1. Karakteritik Responden

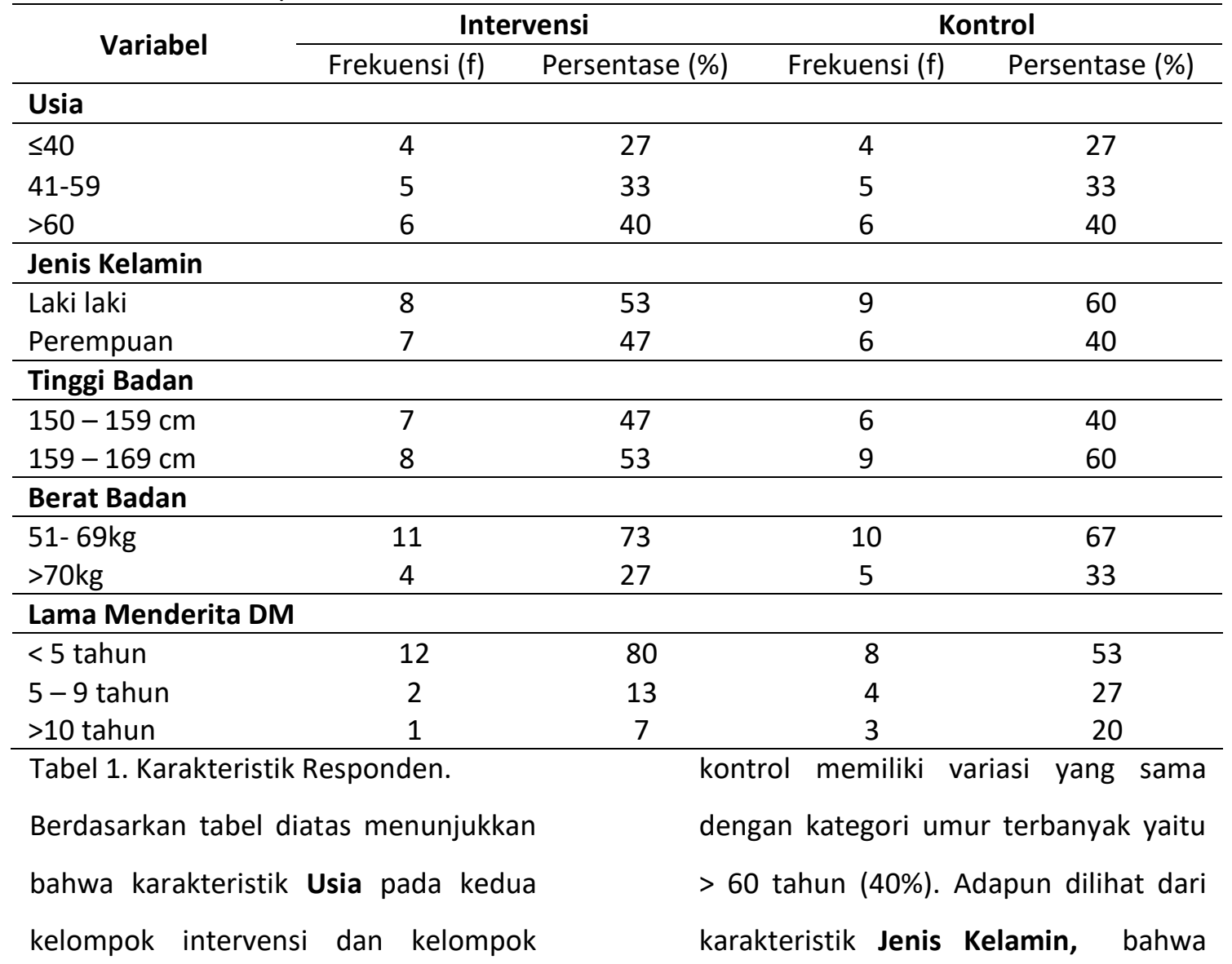


jumlah responden laki- laki lebih banyak daripada responden perempuan pada kedua kelompok responden. Dilihat dari karakteristik Tinggi Badan dengan variasi (150-159 dan 159-169cm Lintervensi 7 pasien laki laki (47\%), perempuan 8 pasien $(53 \%)$ dan kelompok kontrol laki laki 6 pasien ( 40
$\%)$, perempuan 9 pasien (60\%). Dilhat dari karakteristik Berat Badan yaitu berat badan 51- $69 \mathrm{Kg}$ lebih mendominasi daripada berat badan $>70$ Kg. Terakhir bisa dilihat pada Lama Menderita DM ( < 5 tahun ) lebih banyak pada kedua kelompok yaitu intervensi dan kontrol.

2. Sleep Education After Midnight

\begin{tabular}{lcccccc}
\hline \multirow{2}{*}{ Variabel } & \multicolumn{3}{c}{ Intervensi } & \multicolumn{3}{c}{ Kontrol } \\
\cline { 2 - 6 } & Mean & Min-Maks & $\mathrm{Cl}$ & Mean & Min-Maks & $\mathrm{Cl}$ \\
\hline Pre & 8.47 & $7.63-9.3$ & $95 \%$ & 8.40 & $7.62-9.16$ & $95 \%$ \\
Post & 2.46 & $2.0-2.93$ & $95 \%$ & 8.40 & $7.62-9.16$ & $95 \%$ \\
\hline
\end{tabular}

Tabel 2. Sleep Education After Midnight Berdasarkan tabel 2 Menunjukkan adanya peningkatan nilai Sleep education after Midnight (PSQI) dengan

B. Analisa Bivariat

Pada bagian ini akan dijelaskan hasil analisis bivariat dari variable dependen perbedaan nilai Sleep Education After Midnight sebelum dan sesudah dilakukan tindakan dengan variable independen pada menggunakan one sample $T$ test setelah dilakukan intervensi pada kelompok intervensi dibandingkan dengan kelompok kontrol.

kelompok intervensi dan kelompok kontrol serta menjelaskan perbedaan selisih rata-rata nilai PSQI Sleep Education After Midnihgt sebelum dan sesudah pada kelompok intervensi dan kontrol.

1. Uji Normalitas

\begin{tabular}{|c|c|c|c|}
\hline \multirow{3}{*}{ Variabel } & \multirow{2}{*}{ Kelompok } & \multicolumn{2}{|r|}{ Uji Normalitas } \\
\hline & & $p$ value & Keterangan \\
\hline & Intervensi pre (15) & 0.01 & Distribusi Normal \\
\hline \multirow{3}{*}{ Nilai PSQI } & Intervensi post (15) & 0.50 & Distribusi Normal \\
\hline & Kontrol pre (15) & 0.01 & Distribusi Tidak Normal \\
\hline & Kontrol post (15) & 0.00 & Distribusi Tidak Normal \\
\hline \multicolumn{2}{|c|}{ Tabel 3. Uji Normalitas } & & Midnight kelompok intervensi adalah \\
\hline \multicolumn{2}{|c|}{ Berdasarkan tabel 3 dapat disimpulkan } & & distribusi normal karena nilai $p>0.25$, \\
\hline bahwa nilai $f$ & eep Education After & & ada kelompok control 0.00 atau nilai \\
\hline
\end{tabular}


$\mathrm{p}_{\text {value }}<$ dari 0.25 . Sehingga analisis yang

adalah dengan uji Kolmogrov smirnov.

digunakan pada kelompok intervensi

2. Perbedaan nilai PSQI Sleep Education After Midnight sebelum dan sesudah intervensi pada kelompok intervensi.

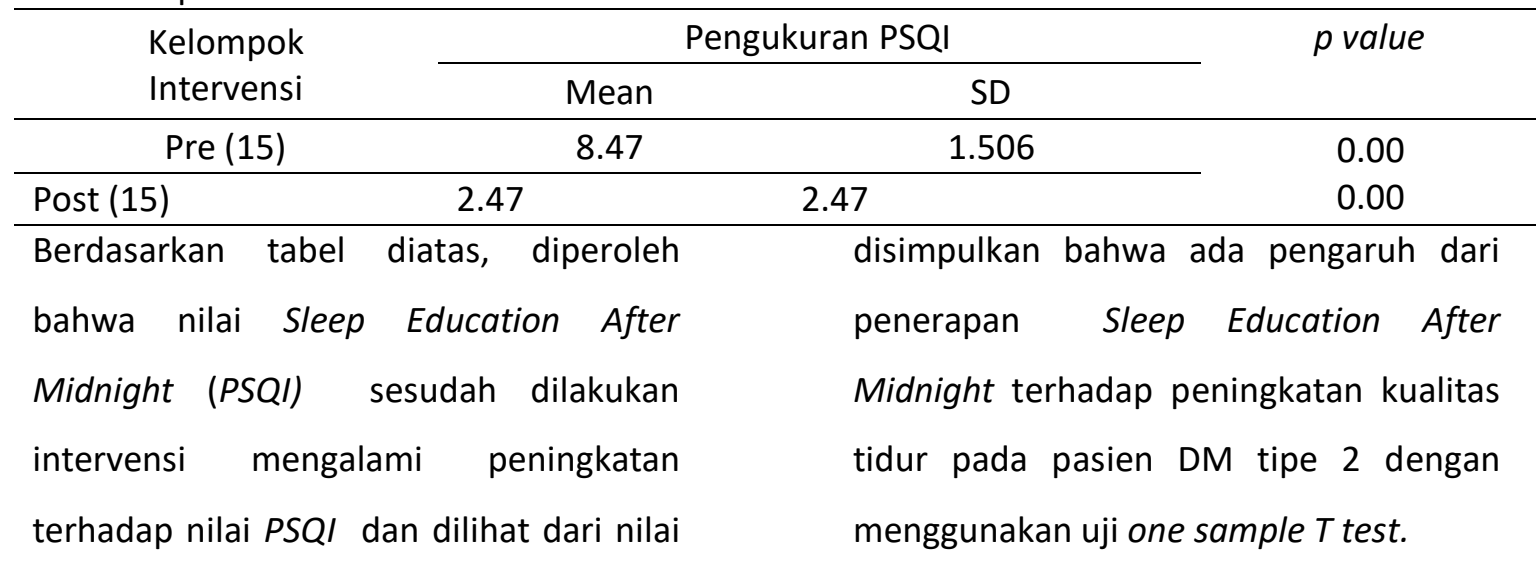

$p$ value $<0.005$ sehingga dapat

3. Perbedaan nilai PSQI sebelum dan sesudah pada kelompok kontrol

\begin{tabular}{cccc}
\hline $\begin{array}{c}\text { Kelompok } \\
\text { Kontrol }\end{array}$ & \multicolumn{2}{c}{ Pengukuran PSQI } & p value \\
\cline { 2 - 3 } & Mean & \\
\hline Pre (15) & 8.40 & 1.404 & 0.00 \\
\hline Post (15) & 8.40 & 1.404 & 0.00 \\
\hline
\end{tabular}

Berdasarkan table 5.5 diatas, didapatkan dari nilai $p$ value $<0.005$, tetapi dapat

bahwa nilai PSQI Sleep Education After

ditarik kesimpulan bahwa tidak ada

Midnight pada kelompok kontrol tidak pengaruh nilai PSQI pada pasien

mengalami peningkatan, sebaliknya

Diabetes Melitus dengan menggunakan

mengalami penurunan, walaupun dilihat

one sample $T$ test.

C. Analisa Multivariat

variabel dependen. Analisis multivariat

Analisis mulitivariat digunakan untuk mengetahui keeratan hubungan antara variabel independen dengan variabel dependen serta sub variabel independen yang digunakan dalam penelitian ini adalah dengan menggunakan uji Anova, dengan variabel terikatnya adalah variable numerik.

yang paling berhubungan dengan 
Kandidat analisis multivariat.

\begin{tabular}{llll}
\hline No. & Variabel & P-value & Keterangan \\
\hline 1. & Usia & 0.046 & Kandidat \\
2. & Jenis Kelamin & - & Bukan Kandidat \\
3. & Tinggi Badan & 0.20 & Bukan Kandidat \\
4. & Berat Badan & 0.25 & Bukan Kandidat \\
5 & Lama Menderita DM & 0.009 & Kandidat \\
\hline Dari tabel 5.6 diatas, diperoleh hasil dari & jenis kelamin tidak kami masukan sebagai \\
analisa seleksi bivariat uji anova & kandidat. Tinggi Badan ( $P$-value $=0.20)$ \\
didapatkan nilai $P$-value untuk variable & artinya Ho ditolak. Kemudian Berat \\
usia (P-value $=$ 0.046), artinya Ho & badan $(P$-value $=0.25)$ artinya Ho di \\
diterima, Jenis Kelamin $(P$-value $=$ data & tolak, dan terakhir Lama Menderita $(P$ - \\
spss tidak keluar nilai), maka kategori & value $=0.009)$ artinya Ho di terima.
\end{tabular}

\section{Permodelan Multivariat}

Tahapan pemodelan diakukan dengan memilih variabel yang dianggap penting untuk masuk dalam pemodelan dengan mempertahankan variabel yang memiliki nilai $p<0.05$ dan mengeluarkan variabel yang mempunyai nilai $p>0.05$. Variabel dikeluarkan secara bertahap dari variabel yang memiliki nilai $\mathrm{p}$ vaule terbesar sampai terkecil. Hasil analisis pemodelan

awal hubungan variable independen dengan variable dependen disajikan pada table 5.7 di bawah ini:

Pemodelan Awal Seleksi Multivariat Pengaruh Variabel Confounding pada nilai PSQI pasien Diabetes Melitus dengan analisis uji Anova.

\begin{tabular}{llll}
\hline No & Variabel & Mean Square & P-Value \\
\hline 1. & Usia & 70.296 & 0.046 \\
2. & Lama Menderita & 1.219 & 0.009 \\
\hline
\end{tabular}

Hasil analisis pada table 5.7 di atas menunjukkan variabel yang harus dikeluarkan dari pemodelan adalah variabel yang nilai $P$ value $>0.005$. Berdasarkan hasil analisis lima variabel dari analisa bivariat, bahwa nilai variabel yang memiliki nilai $P>0.005$ adalah : Jenis kelamin, berat badan, dan tinggi badan, maka di katakan ketiga variable disimpulkan tidak berpengaruh terhadap peningkatan nilai PSQI melalui Sleep Education After Midnight for T2DM. Pada model Summary diperoleh nilai Mean Adjusted Square pada variable usia sebesar 70. 296 dengan $P$ value $<0.005$, dan Variabel lama menderita $1.219 \mathrm{P}$ value 0.009 yang artinya persamaan 
diperoleh mampu menjelaskan peningkatan nilai PSQI.

\section{Pembahasan}

\section{Usia}

Hasil pelaksanaan Evidence base nursing practice menunjukkan bahwa karakteristik usia pada kedua kelompok memiliki variasi yang sama, pada kelompok intervensi dan kelompok kontrol memiliki usia dominan yaitu $\geq 60$ tahun, kemudian usia terendah $\leq 40$ tahun, yang lainnya usia 41-59 tahun. Usia sangat erat hubungannya dengan terjadinya peningkatan kadar glukosa darah dan kejadian diabetes mellitus tipe 2, sehingga dapat mempengaruhi munculnya komplikasi seperti neuropati diabetik atau penyakit kronis lainnya. Neuropati diabetik adalah berupa sekumpulan gejala yang terjadi pada saraf perifer, menyebabkan adanya rasa kebas, baal ataupun hilang sensasi (Mildawati et al., 2019). Diabetes Melitus merupakan suatu penyakit metabolik yang ditandai dengan hiperglikemia, polidipsi, poliuria, polifagia, dan penurunan berat badan. Komplikasi Diabetes Mellitus dapat dibagi menjadi angiopati, neuropati dan kombinasi keduanya. Angiopati pada arteriole dan pembuluh kapiler terjadi karena rendahnya metabolisme kadar gula darah pada penderita Diabetes Melitus. Hal tersebut bisa karena disebabkan salah satunya karena usia pada pasien diabetes mellitus. (Krismanita et al., 2017). Kadar kadar gula darah (Glukosa) tidak terkontrol (GDP >100 dan GDPP >140 mg/dl) akan menyebabkan komplikasi jangka panjang, baik makrovaskular maupun mikrovaskular. Penelitian yang ada menyatakan bahwa usia $\geq 60$ tahun berkaitan dengan komplikasi kronik nefropati diabetik dan penyakit pembuluh darah perifer pada penderita diabetes melitus karena fungsi tubuh secara fisiologis menurun karena proses aging sehingga terjadi penurunan sekresi atau resistensi insulin sehingga kemampuan fungsi tubuh terhadap pengendalian glukosa darah kurang optimal (Kusdiyah et al., 2020). Faktor risiko yang mempengaruhi komplikasi neuropati diabetik ialah lama menderita diabetes, usia, jenis kelamin, hasil cek gula darah sewaktu, riwayat merokok penyakit penyerta dan amputasi (Khana $R, 2016)$. Proses menua yang berlangsung setelah usia 30 tahun mengakibatkan perubahan anatomis, fisiologis dan biokimia. Perubahan dimulai dari tingkat sel, berlanjut pada tingkat jaringan dan organ yang dapat mempengaruhi fungsi keseimbangan tubuh. Komponen tubuh yang dapat mengalami perubahan adalah 
sel beta pankreas yang menghasilkan hormon insulin, sel-sel yang menghasilkan glukosa, sistem saraf, dan hormon lain yang mempengaruhi kadar glukosa. Lapisan intima dan media pembuluh darah pada proses penuaan terus mengalami remodeling sehingga terjadi peningkatan deposisi kolagen dan degenerasi elastin sehingga pembuluh darah kehilangan elastisitasnya dan menjadi kaku (Wang et al, 2012). Disamping itu, proses penuaan

\section{Lama menderita diabetes mellitus}

Hasil penerapan EBNP menunjukkan bahwa karakteristik responden pada kelompok intervensi penerapan sleep education dan kelompok kontrol memiliki lama riwayat diabetes mellitus yang dominan yaitu $\leq 5$ tahun. Lamanya waktu seseorang mengalami Diabetes Melitus dapat memperberat resiko komplikasi Diabetes Mellitus diantaranya komplikasi mikrovaskular maupun makrovaskular. komplikasi Diabetes Mellitus juga berkaitan dengan penurunan fungsi sel beta pankreas yang menyebabkan komplikasi secara umum pada pasien dengan lama menderita DM 5 -10 tahun. Penurunan fungsi sel beta pankreas akan berdampak pada produksi insulin yang akhirnya menimbulkan komplikasi (Kusdiyah et al., 2020). Penelitian yang mengakibatkan perubahan pada dinding pembuluh darah sehingga dapat berpengaruh pada kualitas tidur pasien dan dapat mempengaruhi nilai $P S Q I$ yang menandakan adanya gangguan pola tidur, sehingga bisa disimpulkan bahwa usia tua dapat mempengaruhi nilai PSQI. (Gustimigo, 2015). Berdasarkan penelitian, usia yang terbanyak terkena Diabetes Mellitus adalah $>45$ tahun. (Bhatt et al., 2016)

dilakukan oleh Yuhelma menunjukkan bahwa 27 (56,3\%) pasien diabetes melitus dengan komplikasi nefropati diabetik dengan lama menderita Diabetes Mellitus selama $\leq 5$ tahun, dan hanya $21(43,7 \%)$ pasien diabetes melitus dengan komplikasi nefropati diabetik dengan lama menderita Diabetes Mellitus selama $>5$ tahun. Komplikasi terjadi antara 5-10 tahun. Musyafirah dalam penelitiannya menyatakan bahwa 108 (90\%) pasien dengan lama menderita Diabetes Mellitus selama $>5$ tahun, lebih tinggi dari $12(10 \%)$ pasien dengan lama menderita Diabetes Mellitus selama $\leq 5$ tahun. Komplikasi nefropati diabetik dan atau penyakit pembuluh darah perifer yang terjadi pada penderita Diabetes Melitus yang telah menderita 10 tahun atau lebih akan berdampak pada 
peningkatan kadar glukosa darah tidak terkendali sehingga akan memicu munculnya komplikasi penyakit pembuluh darah perifer. Lama menderita diabetes lebih dari 10 tahun memiliki resiko 19 kali lebih tinggi dibandingkan pasien dengan diabetes kurang dari 10

3. Perbedaan nilai PSQI sebelum dan sesudah intervensi pada kelompok intervensi

Sleep Education After Midnight (PSQI) sesudah dilakukan intervensi mengalami peningkatan terhadap nilai PSQI dan dilihat dari nilai $p$ value $<0.05$ dapat disimpulkan bahwa ada pengaruh dari penerapan Sleep Education After Midnight terhadap peningkatan kualitas tidur pada pasien diabetes mellitus type 2. Rata-rata nilai PSQI sebelum intervensi pada kelompok intervensi Sleep Education After Midnigt yaitu 8.47 sedangkan rata-rata PSQI sesudah intervensi Sleep Education After Midnight yaitu 2,47. Hasil statistik uji $T$ ( $T$ test untuk nilai $P=0,00(P<0,05)$. Maka dapat ditarik kesimpulan bahwa 1) secara statistik PSQI sebelum diberikan Sleep Education After Midnight berbeda dengan nilai PSQI sesudah diberikan perlakuan Sleep Education After Midnight. 2) ada perbedaan yang signifikan antara nilai PSQI sebelum dan tahun (Betteng R, dkk, 2014). Sedangkan faktor lain seperti kondisi penyakit penyerta atau darah tinggi tidak berkaitan secara signifikan dengan neuropati perifer diabetik (Smeltzer et al,2010).

sesudah diberikan perlakuan Sleep Education After Midnight.

\section{Pengaruh faktor perancu (Confounding)} terhadap peningkatan nilai PSQI pada pasien Diabetes Melitus tipe 2.

Hasil penerapan EBPN menunjukkan bahwa berdasarkan uji multivariat dengan menggunakan uji anova.

a. Usia

Hasil penerapan EBPN terdapat pengaruh usia terhadap peningkatan nilai PSQI dengan hasil seleksi multivariat uji annova pada variable confounding usia dengan variable dependen peningkatan nilai PSQI pada pasien diabetes mellitus dengan nilai $p$ value 0.046 atau ( $\mathrm{P}$ value $<$ 0.05 ) yang artinya ada pengaruh usia terhadap pengingkatan nilai PSQI pada pasien diabetes mellitus tipe 2 . Hasil penerapan EBPN ini tentang usia sejalan dengan analisis seiring bertambahnya usia, khususnya diatas 45 tahun mulai terjadi peningkatan intoleransi glukosa. Adanya proses menua menyebabkan gangguan pada 
insulin dan sel beta pankreas yaitu berkurangnya kemampuan sel beta pankreas dalam memproduksi insulin. Disamping itu, proses penuaan mengakibatkan perubahan pada dinding pembuluh darah sehingga dapat berpengaruh pada kualitas tidur pasien dan dapat mempengaruhi nilai PSQI yang menandakan adanya gangguan pola tidur, sehingga bisa disimpulkan bahwa usia tua dapat mempengaruhi nilai PSQI (Gustimigo, 2015).

b. Lama menderita diabetes melitus Hasil penerapan EBN ini terdapat pengaruh lama menderita diabetes mellitus terhadap peningkatan nilai PSQI dengan hasil seleksi bivariat uji anova variable confounding lama menderita diabetes mellitus dengan variable dependen peningkatan nilai PSQI pada pasien diabetes mellitus dengan nilai $p$ value 0.09 atau $<0.05$ yang artinya lama menderita diabetes mellitus masuk kandidat dalam permodelan multivariat dengan nilai $p$ value $<0.05$ yang ada pengaruh lama menderita diabetes mellitus terhadap pengingkatan nilai PSQI terhadap sleep education after midnight. Dari kedua kelompok yaitu $\leq 5$ tahun dan maksimal > 10 tahun. Lamanya waktu seseorang mengalami diabetes mellitus dapat memperberat resiko komplikasi Diabetes Mellitus salah satunya adalah penurunan kualitas tidur pasien diabetes mellitus yang bisa disebabkan oleh faktor fisik dan psikologis.

Lama menderita diabetes mellitus tipe 2 tidak berdiri sendiri sebagai faktor memburuknya nilai PSQI, diantaranya Jenis kelamin, dan berat badan. Menurut America Diabetic Asociation (ADA) penyakit diabetes mellitus dapat ditandai dengan banyak minum, banyak makan, sering buang air kecil dan terjadi penurunan berat badan. Penurunan berat badan dapat terjadi penurunan massa otot tubuh. Apabila terjadi penurunan massa otot di pada nasofaring dan orofaring dapat terjadi Obstructive Sleep Apnea (OSA) yang pada akhirnya biasa mempengaruhi berat badan (Kekenusa et al., 2013). Begitupun dengan jenis kelamin, berdasarkan data World Health Organization (WHO) tahun 2013 terdapat 347 juta orang di seluruh dunia mengidap diabetes mellitus WHO memproyeksikan bahwa diabetes mellitus akan menjadi penyebab utama kematian pada tahun 2030. Berdasarkan data riset kesehatan dasar tahun 2013, secara nasional prevalensi diabetes mellitus tampak terjadi peningkatan jika dibandingkan dengan data riskesdas 
tahun 2007. Ditemukan pula bahwa prevalensi diabetes mellitus menurut karakteristik jenis kelamin dengan usia 15 tahun keatas pada perempuan cenderung lebih tinggi daripada lakilaki. (Tigauw et al., 2014) . Tetapi dalam hal ini berat badan tidak kami masukan kedalam pembahasan,

\section{DAFTAR PUSTAKA}

1. Bhatt, H., Saklani, S., \& Upadhayay, K. (2016). Anti-oxidant and anti-diabetic activities of ethanolic extract of Primula Denticulata Flowers. Indonesian Journal of Pharmacy, 27(2), 74-79. https://doi.org/10.14499/indonesianjph arm27iss2pp74

2. DHHS. (2020). National Diabetes Statistics Report, 2020. National Diabetes Statistics Report, 2.

3. DURI KARTIKA, C., RI, kementrian kesehatan, Studi, P., Dokter, P., Kedokteran, F., Udayana, U., מזלי, ר., Oliver, J., Abdul Majid, J., Sulaiman, M., Zailani, S., Shaharudin, M. R., Saw, B., Wu, C. L., Brown, D., Sivabalan, P., Huang, P. H., Houston, C., GoobermanHill, S., ... Saskia, T. I. (2015). No 16(1994), 1-37.

\section{http://eprints.ums.ac.id/37501/6/BAB}

\section{$\underline{\text { II.pdf }}$}

4. Gustimigo, Z. P. (2015). Kualitas Tidur Penderita Diabetes Melitus The Sleep karena pada uji annova berat badan dan jenis kelamin ternyata tidak berpengaruh terhadap peningkatan kualitas tidur pasien, hasil acak kuesioner PSQI.

Quality Of Patient With Diabetes Mellitus. Fakultas Kedokteran Universitas Lampung, 4(November), 133-138. http://jukeunila.com/wpcontent/uploads/2015/11/133-138-

\section{ZELTA.pdf}

5. Kekenusa, J. S., Ratag, B. T., \& Wuwungan, G. (2013). Analisis Hubungan antara Umur dan Riwayat Keluarga Menderita DM dengan Kejadian Penyakit DM Tipe 2 pada Pasien Rawat Jalan di Poliklinik Penyakit Dalam BLU RSUP Prof. Dr. R. D. Kandou Manado. Journal Kesmas Universitas Sam Ratulangi Manado, 2(1), 1-6.

6. Krismanita, D., Naftali, Z., \& Hellmi, R. (2017). Hubungan Lamanya Menderita Diabetes Melitus Dengan Terjadinya Peningkatan Ambang Pendengaran. Diponegoro Medical Journal (Jurnal Kedokteran Diponegoro), 6(2), 470-479.

7. Kraljić, K., Škevin, D., Pospišil, M., Obranović, M., Neđeral, S., \& Bosolt, T. (2013). The nutrients and their metabolism. Journal of the American Oil Chemists' Society, 90(4), 719-726. 
https://doi.org/10.1002/047167849X.bi $\underline{0004}$

8. Kusdiyah, E., Makmur, M. J., Berlian, R., \& Aras, P. (2020). Darah Perifer Pada Penderita Diabetes Mellitus. E-SEHAD, 1(1), 19-32.

9. Li, M., Li, D., Tang, Y., Meng, L., Mao, C., Sun, L., Chang, B., \& Chen, L. (2018). Effect of Diabetes Sleep Education for T2DM Who Sleep after Midnight: A Pilot Study from China. Metabolic Syndrome and Related Disorders, 16(1), 13-19. https://doi.org/10.1089/met.2017.0069

10. Mildawati, Diani, N., \& Wahid, A. (2019). Hubungan Usia, Jenis Kelamin dan Lama Menderita Diabetes dengan Kejadian Neuropati Perifer Diabateik. Caring Nursing Journal, 3(2), 31-37.

11. Oliver, J. (2019). Bab li Tinjauan Pustaka Aplikasi. Hilos Tensados, 1, 1-476.

12. Riskesdas, K. (2018). Laporan Nasional RKD2018 FINAL.pdf. In Badan Penelitian dan Pengembangan Kesehatan (p. 198).

13. Rusmania, N. (2015). No Title 151, 1017.https://doi.org/10.1145/3132847.31 $\underline{32886}$

14. Rias, Y. R., \& Sutikno, E. (2017). Hubungan Antara Berat Badan Dengan Kadar Gula Darah Acak Pada Tikus Diabetes Mellitus. Jurnal Wiyata, 4(1), 72-77.
15. Saeedi, P., Petersohn, I., Salpea, P., Malanda, B., Karuranga, S., Unwin, N., Colagiuri, S., Guariguata, L., Motala, A. A., Ogurtsova, K., Shaw, J. E., Bright, D., \& Williams, R. (2019). Global and regional diabetes prevalence estimates for 2019 and projections for 2030 and 2045: Results from the International Diabetes Federation Diabetes Atlas, 9th edition. Diabetes Research and Clinical Practice, $157,107843$. https://doi.org/10.1016/i.diabres.2019. $\underline{107843}$

16. Surgawa,E.,\& Nikado, H. (2019). Journal of Chemical Information and Modeling, 53(9), 1689-1699.

17. Tigauw, J. H., Kapantow, N. H., \& Sondakh, R. C. (2014). Hubungan antara Jenis Kelamin dengan kadar Adiponektin pada Penderita Diabetes Melitus Tipe 2 di Kota Manado. Fkm Unsrat, 1, 1-7.

18. Wahyuningsih, A. S., Huriah, T., Sari, N. K., Surya, S., Kediri, M. H., Universitas, K., \& Yogyakarta, M. (2016). Hubungan Kadar Gula Darah Dengan Insomniapada Penderita Diabetes Melitus. The Indonesian Journal of Health Science, 7(1), 54-63. 